Meta

Journal des tradlucteurs

Translators' Journal

\title{
Foal on the Pitchfork (Yusuf Eradam)
}

\section{Berrin Aksoy}

Volume 47, numéro 1, mars 2002

URI : https://id.erudit.org/iderudit/008003ar

DOI : https://doi.org/10.7202/008003ar

Aller au sommaire du numéro

Éditeur(s)

Les Presses de l'Université de Montréal

ISSN

0026-0452 (imprimé)

1492-1421 (numérique)

Découvrir la revue

Citer cette note

Aksoy, B. (2002). Foal on the Pitchfork (Yusuf Eradam). Meta, 47(1), 145-147.

https://doi.org/10.7202/008003ar d'utilisation que vous pouvez consulter en ligne.

https://apropos.erudit.org/fr/usagers/politique-dutilisation/ 
GonzÁlez Manet, E. (1984): Cultura y comunicación, minima ensayo. LA HAVANE: Editorial Letras Cubanas.

Gregori Torada, N. (1989) : «Fundamentos para el Establecimiento de una política lingüística en Cuba». Dans El Español en Cuba. LA HAVANE: Facultad de Artes y Letras, Universidad de la Habana, p. 245-267.

—. «Proposición de una política lingüística nacional ». Anuario L/L-Estudios Lingüísticos 23: 87111.

Ortiz, F. (1993) : «Los factores humanos de la cubanidad». Dans Ortiz, Fernando. Etnia y sociedad. I. Barreal (dir.). LA HAVANE: Editorial de Ciencias Sociales, p. 1-20.

Peñalver, F. J. M. (1977) : «Memoria que promueve la edición de un dicionario provincial de la Isla de Cuba. Leída en la Junta ordinaria de 29 de octubre de 1795. Por el R. P. Mtro. Fr. José María Peñalver, del Orden de Ntra Señora de la Merced, Socio de número ». Dans Alonso, Gladys y Angel Luis Fernández, (dir.). Antología de lingüística cubana, Tomo I. LA HAVANE: Editorial de Ciencias Sociales, p. 13-20.

VAldés Bernal, S. (1994): Inmigración y lengua nacional. LA HAVANE: Editorial Academia.

\section{Foal on the Pitchfork (Yusuf Eradam)}

I easily get upset, true. They say once I lose my temper, I can't control myself. That's how my father used to boast to his hunting friends. Of course he is right. All this is because of me. It's because I make up my mind right away. My father didn't like my hands. They were so small, he used to say, I should have been born a girl. How can I train my father? Who am I to train my father? My father. The most notorious trainer of our country. $\mathrm{He}$ puts his family first, and then comes the rest. $\mathrm{He}$ used to say that, members of the family should give a hand to one another, or else the family would fall to pieces, would crumble, would be torn apart, heaven forbid. That was what my father used to tell my elder brothers and sisters every time we sat at the supper table, and me especially, the youngest son, while shaking his forefinger at me. A father is like a "stretcher," he keeps the family together, he would say. I hadn't known what a stretcher meant until I saw the men laying the parquet in our farmhouse.

My mother would not utter a sound. She would keep her eyes on my father's hands for a while, then taking courage from her eyes fixed below, she would start to pass out the soup. My mom would begin household chores with the name of "Allah," too. In my eyes, Allah used to go between the tip of my father's forefinger and my mother's eyes. I heard Allah at that supper table. Allah looked at me through the eyes of my mother and said "The scholar's son becomes a tyrant, the tyrant's son becomes a scholar." I thought that one day my father's forefinger would come off and stick my mother in the eyes. My father's hands were so big, so big they were.

I was only four when my father killed "Olive." While I was swimming in the creek near our home, I heard Olive wailing. I ran. I couldn't get there in time. My father had already hanged him on a big plum tree. My father's hands were so big, he could use a shovel as easily as a toothpick. He wasn't the least affected as he hit Olive with the shovel. "There you are, you bloody dog. I take all the pains to catch that woodcock, and there now, I'll give you a good lesson, to hell with you!" The red which was running down Olive's head was filling his eyes and washing out his body, it created a small pool on the earth. Soon Olive was silent. His last sound was so weak, it was as if he was whispering "thyyyyme" from his throat filled with red, the "iiii" sounding like the wheat leaves being crushed between the rusty notches of the pitchfork. I could not make a sound, I could not, I was afraid that Allah calling me from my mother's eyes, would pass on to my father's hands and say something to me from there. I thought I would die. Death was now in my father's shovel-like hands. I didn't want to meet my father's Allah. And I didn't kill Olive, that I know. My father is lying.

Someone, probably my mother, is pulling my hand. She doesn't want me to see it. "Patos! $\mathrm{He}$ wants the boy to be like him," she whispers to my nanny. My nanny, who tells me stories of amourous clouds, looks down. I am dying, nanny. Tell me a story. My nanny's bosom smells of thyme. How do my eyes soak the thyme. My mother's velvety hands, my nanny's thyme-smelling bosom.

I was so scared that my ex-soldier father would train you the same way. But you had entered my world like cotton balls, like colorful festival ballons, like my first teacher's affectionate strokes. You expanded in me like the creek I bathed in. It looked like you knew it while you used to hop around like a deer, it was like you were a boy waiting for his summons to arrive, you were too young to recieve military service summons. I died, that you would receive the same training.

My father used to get me toy guns to play with. I would play with my marbles. I would play dahlia. I would play notak with my pals. I would play five stones and jump rope. My father's toys were too big for my hands. Big guns, rope, fishing rod, rifle, horsewhip... aren't you a man, he would ask. Hey woman, his mother, is this boy some sort of a mix?

I always run to Ali, to the most friendly shepherd in the whole village. Ali would tell me the names of the sheep. He knows them all, and never 
beats them. Ali's hands are big too, but he only holds a twig and waves it in the air. The twig strokes the sheep. I get lost in Ali's stories. 'Where have you been, you devil?' yells my father. His big hand slaps my face. 'I wonder if Allah created you, you jerk,' he says. I stumble towards my nanny, I see my nanny and my mom hold out their hands. How would I know which direction I would be tossed away by the force of those big hands? I fall on the earth, waving my arms in the air. I am a kite, I fly, my rope in the hands of my father. My jaw hits the edge of the furnace where my favorite meal "keshkek" is being cooked, where the village women gather to make "shepe." That's how I got the scar on my jaw.

It is my father who raised me to be so timid and frightened. I learned to obey. I should not be afraid of the blowing wind, of the howling dogs, or of all the threatening things. I should be brave, he would say, I could survive only when I had felt the breath of death on my neck. This is why Hemingway was so fond of bull-fighting, he used to say. My father loved bull-fighting, too. He thought he was a matador. He would tell me about the bull fights he had watched during his business trips to Spain, I would think of the bull, but mostly, of the horse. A horse, who could race with the wind in the meadows, can be slain by an accidental blow from the horns of the bull, he used to say. While walking around mightily, the bull which missed the matador could as well blow up the stomachs of the poor horses which carry the assistants of the matadors who infuriate them by prodding the bull with their sticks. Lucky are those on the horses who could save their lives from those blows! he would say. First be tamed, then get your stomach burst out! It's hard to be a man. I can't be a man. They would call out "Ole!.” I can't say that. I can't say "Ole!"

And he would never give up wearing those gloves. I would die when he put on those gloves. I would turn my face to the wall. I wouldn't want to see.

My father had many stories to tell. I learned so much from him. My father loved to talk about the greatest tragic hero. "Tell me, you wimp, what is it that has four legs in the morning, two at noon, and three in the evening? Ha, ha, can't guess, right?" Man. I didn't know the answer the first time, then later each time he directed the question at me, I would cry out "Man!," like a soldier yelling out "Aye, aye sir!" to his commander, and my father would stroke my head roughly. The Sphinx asked Oedipus this riddle about man. My father says it's destiny. He says it's Allah's will. When Oedipus of Tebai had four legs, the oracles said that this baby was going to kill his father, marry his own mother, and be brother to his own children. His father the
King who had a fear of dying, gave baby Oedipus to a shepherd and ordered that the baby be killed on the mountains. How big my father's hands were.

And he never gave up using the horsewhip. When he did so, I'd say "here we go," cover my ears and turn my face to the wall. I wouldn't want to hear.

Pitying the baby, the shepherd gave the baby to a childless couple in a remote place. And then the omen materialized. Oedipus, who became a hero when he had answered Sphinx's riddle correctly only realized that the omen had taken place when the shepherd recognized him from the birthmark on his ankle. Only then did he know who he really was. So that was it. "One musn't boast about today but be apprehensive of tomorrow," my father used to say. I used to think smoking cigars would suit him better than cigarettes. He used to wear thick gloves to keep his hands from tearing up when holding the rope. The hands of those who read books wouldn't have corns on them, he would say. My father's hands ached. My hands ache now, too but I know that I am not the cause of your death, either. My father cannot lie anymore.

And he never gave up putting on his boots. When he did so, I would nearly faint of fear. I wished I would die, I remember telling myself. Die. And turn my face to the wall forever.

I woke up to your voice, on that day when they brought you to the farm. My father had just arrived from town. I don't know what he does in town. My mother says he is doing some sort of tricks there but all the same... My uncle says he is the Prime Minister's right hand. Even members of the Parliament are afraid of him. The farm is filled with joy. Both my father and you have arrived. You, the most beautiful foal in the world. Foal. You were so beautiful that I was totally unable to give you a name. So I'll call you 'foal'. Please forgive me. It is this man standing next to you, holding on your ropes, it is this bully who won't let me have you. Who thinks I am too much for you. I begged and I yelled, pleaded with my father, pleaded with them all, not to train you. I die every time a foal is trained. They say your arrogance can only disappear when you have those oily ropes and nooses on your neck, your trotting around the world with an air of utmost dignity and grandeur can only be tamed when you think you are going to be strangled, when the ropes tighten around your neck from all around... when your eyes pop out Foal... They say I am a very good boy, too, look how much everybody likes me, you are going to be like me they say, obedient and cute. Otherwise, they say, you would be rebellious, you would wander off. They have to tighten the rope until you are breathless, this is called "foal strangling" they say. There is no harm in this, they say, or else the foals 
run around deliriously, scared of even a plastic bag, they can only become a real horse when they get so close to death, when they get breathless, only when they breathlessly feel death on their necks, they say...

My father put on his gloves. I died. My father picked up his horsewhip. I wished I could melt into the wall. I did not cover my ears this time. I see your eyes, your slim ankles, I was a kite among the clouds the moment I saw you. I flew over cliffs and hills with you, but only with you could I free myself from my rope, otherwise it wouldn't be flying for real, just like the flying of a kite isn't. The end of my rope is in my father's hands, Foal. This is not the way I want to fly. The clouds ask me to break off my ropes. "Follow us," the clouds say, I can't, my father holds my rope. He holds it tighter and tighter. Hold out your hands, he yells. I run faster and faster... my hands stretched out, I find myself sitting in my bed soaked in sweat. Did you have another nightmare my son, says my mother, my nanny, the moon refracting on her henna stained palms, sighs deeply. My nanny turns to the other side on the mattress resting on the floor, my arms go under the quilt with the help of my mom's velvety hands. The moonlight is like my mother's misty eyes.

My father picked up his horsewhip. If only I couldn't hear its sound on your back.

I will not. And I did not.

But I heard my father putting on his boots. "This time we will strangle you with the ropes I brought from Ankara, boys, I brought imported torture ropes."

I know torture. The floormen who laid the parquet on the floor of our farmhouse were tightening the wood with a rubberlike belt. They said this was called "stretching" when I asked about it. Or "torture," or "pitchfork," they had said. It was used to keep the parquet pieces intact, to prevent them from loosening. My father used to compare himself to a stretcher. I keep this family together, he would say. You would all be devastated without me, he used to say. If not for my father, we would have been scattered all around, and become food for the birds and the wolves. How he liked this metaphor. Being food for the birds and the wolves.

We have. We'd rather be. The sun was so scorching that day. Foal, you were going to be tamed.With the first noose on your neck, your eyes popped out... I saw those eyes later in Picasso's Guernica. You pulled on the rope on your neck, and started to run, and... so did I... don't.

This time I'm going to make it. I'll die if I

My father, screaming "take this shit out of my way, he's going to be smashed!," was running at the same time. I am the shit. Foal, what made you run to the cliff that opened up to the valley behind the farm? I would have liked to watch the stars with you in that valley which at night I now think resembles the sea.

I got carried away. When I saw you flying down the cliff like a kite whose rope broke off...

"Foooal!"

"Foal," what a lovely word. The mouth gets ready for a smile when you utter it. My father threw a noose made of the imported rope at that moment and with his huge hands as competent as ever, he expertly put the rope around your delicate neck. Your eyes were Guernica again. My eyes, my eyes were Guernica,too. My father was trying to pull you up the cliff. Don't stretch it, Father. He's just a foal. My father pulls you up slowly. What has happened to your eyes? Soon, more imported ropes will be around your neck, the torture will begin again. I looked at my hands. Your hands are so small, you jerk, like a girl's hands! Hold out your hands, hey guys, see what a man's hands look like! The men at the rak table will look at my hands again, and they will laugh with their dirty teeth showing. He should have been a girl, man! they would say and laugh. Lemme see your hands!!!

I'll die if I can't make it this time.

I held my hands out. My father's boots on the edge of the cliff slipped. My father is waving his hands as if he wants to fly.

"Foooal!!!"

I don't want my father to strangle foals. Don't let him put on those stiff leathery gloves, don't let him strike with the whip, or tread on my dreams with his boots. I have had enough, we have had enough of my father's might. Oh, foal. I wanted them not to tame you, not to teach you to obey. I did not want them to make you bow down to them, all I wanted was...

Down the cliff with my father and right on the crossroads... In the space between you lies the rope. Its mark is still on your neck. My father lies on the ground like the Sphinx. His head bent down like the Sphinx.

"Both have broken their necks," someone said. I heard him.

You have four legs, my father has two.

Now I am far away. I will never return to those sinister lands where Foals are strangled and Olives are murdered. Motherland. Pitchfork. The three-notched fork.

I don't jump rope. My mother's velvety hands are on me, my nanny's thyme-smelling bosom on my mind and your eyes always in front of my eyes. That's why, Foal. I have survived.

My father loved to strangle foals. Otherwise, he said, man can not survive.

Berrin AKsoy

Hacettepe University, Ankara, Turkey June, 2000, Ankara 


\section{DIRGENDEKİ TAY}

\section{Yusuf Eradam}

Ben çabuk öfkeleniyorum, doğru. Gözüm kararmaya görsünmüş ne yaptığımı bilmezmişim. Babam böyle böbürlenirdi av arkadaşlarına. Haklı. Bütün bunlar benim yüzümden. Hep ani karar vermemden. Babam. Babam ellerimi sevmezdi. Küçücükmüş ellerim, kız olacak bir şeymişim. Babamı nasıl terbiye edeyim ki? Ben kimim ki terbiye edeyim babamı? Babam. Memleketin en namlı terbiyecisi. Ailem der de başka bir şey demez babam. Aile fertleri hep omuz omuza olmalıymış, yoksa o aile un ufak olurmuş, dağılıverirmiş, kurda kuşa yem olmak varmış Allah göstermesin. Babam, ne zaman birlikte yemek yesek, abilerime, iki ablama ve özellikle de en küçük oğlan bana işaret parmağını sallaya sallaya söylerdi böyle. Gerdirme gibidir baba, aileyi bir arada tutar, derdi. Çiftlik evine parkeciler gelene kadar bilmezdim "gerdirme" ne demek.

Annem hiç ses çıkarmazdı. Gözlerini babamın ellerinden ayırmazdı bir süre, sonra da önüne düşen gözlerinden aldığı cesaretle başlardı çorbayı dağıtmaya, Allahın adıyla başlardı o da işe. Allah bana göre, babamın işaret parmağının ucuyla annemin gözleri arasında gidip gelirdi sofrada. Allahı duydum ben o sofrada. Annemin gözlerinden bana baktı ve dedi ki "alimin oğlu zalim, zalimin oğlu alim olur". Babamın işaret parmağ yerinden çıkacak ve annemin gözlerine saplanacakmış gibi gelirdi.Babamın elleri kocamandı, babamin elleri.

Daha dört yaşındaydım babam Zeytin'i öldürdüğünde . Ben evin yanındaki derede çimerken duydum Zeytin'in can havliyle havlamasını. Koştum. Yetişemedim. Babam çoktan Zeytin'i bir erik ağacına asmıştı. Kocamandı elleri babamın, küreği kürdan gibi rahat kullanırdı. Zeytin'in başına başına indirirken de rahattı. Al sana itoğlu it! Ben o çulluğu yakalayacağım diye neler çektim, geber, geber de aklın başına gelsin. Zeytin'in başından akan kırmızı, Zeytin'in gözlerine doluyor, oradan bütün gövdesini yıkayıp yerde minicik göl oluyordu. Çok geçmedi sesi kesildi Zeytin'in. Son çıkardığı ses incecikti, sanki fısıltıyla "kekiiiiiik" diye bağırıyordu. Kırmızı dolmuş boğazında "iiiiii" dirgenin paslı dişleri arasında buğday başakları gibi. Ben gıkımı çıkaramadım çünkü annemin gözlerinden seslenen Allah, babamın ellerine geçer de oradan bana birşeyler derse diye korktum. Ölürüm sandım. Ölüm, babamın kürek gibi ellerindeydi artık. Babamın Allahı'yla tanışmak istemiyordum. Hem Zeytin'in ölümüne ben sebep olmadım, bunu biliyorum. Babam yalan söylüyor.

Annemdir, biri elimden çekiştiriyor. Görmeyeyim istiyor annem. "Patos! Çocuğu da kendine benzetecek ille," diye fisıldiyor emeteme. Bana sevdalı bulutların masallarını anlatan emetem de başını önüne eğiyor. Ben ölüyorum emete. Bana masal anlatsana. Emetemin bağrı kekik kokuyor. Gözlerim nasıl da ıslatıyor kekiği. Taylığım. Annemin kadife eli, emetemin kekik bağrı.

Asker eskisi babam seni de öyle terbiye edecek diye öyle korktum ki. Pamuk helva gibi girmiştin oysa dünyama, rengarenk bayram balonları gibi, ilk öğretmenimin saçımı 
okşayışı gibi. İçinde çimdiğim dere gibi yayıldın içime. Ceylanlar gibi sekerken biliyor gibiydin, yeni yetme bir delikanlıydın da sanki savaşa gideceğin emri gelecekti, ufacık bir çocuktun da daha asker celbini alıyordun. Seni de öyle terbiye edecekler diye öldüm.

Babam bana oyuncak silah alırdı oynayayım diye. Ben bilyalarımla oynardım. Notak oynardım. Dalya oynardım arkadaşlarımla. Beş taş oynardım, ip atlardım. Ellerime büyük gelirdi babamın oyuncakları. Kocaman silah, sicim, olta, tüfek, kırbaç...erkek değil miymişsim yoksa ben? Annem karısı, bu oğlan karışıkmıymış?

Ben hep köyün en tatlı dilli çobanının, Ali abinin yanına kaçıyorum. Ali abi bana bütün koyunların adını sayıyor. Hepsini tanıyor, hiçbirine vurmuyor. Ali abinin elleri de kocaman ama onun elinde bir ufacık dal havaya sallayıp duruyor. Koyunları okşuyor dal. Ali abinin hikayelerine dalıyorum. Nerde kaldın lan, diye bağırıyor babam. Kocaman eli yüzüme yüzüme iniyor. Seni de Allah mı yarattı lan köpoğlu köpek, diyor. Ben emeteme doğru sendeliyorum, emetem ile annemin aynı anda bana doğru ellerini uzattıklarını görüyorum. Ben o kocaman elin gücüyle ne yana savrulacağıma karar veremem ki. Kollarımı kanat gibi sallayarak düşüyorum. Bir uçurtmayım ben, uçuyorum, ipim babamın elinde. En sevdiğim yemek keşkeği yaptığımız yere, annemle köy kadınlarının bir araya gelip şepe yaptıkları tandırın kenar çıkıntısına çarpıyor çenem. Çenemdeki bu yarık izi oradan kalma.

Babamdır beni böyle korkak, ürkek yetiştiren. Boyun eğmeyi öğrendim ben. Oysa, ne rüzgardan, ne itin ürümesinden, ne de üstüme başıma değenlerden ürkecekmişim, yiğit olacakmışım; ben ancak ölümle yüzyüze gelirsem, ölümü ensemde bu kadar yakın hissedersem hayatta kalabilirmişim, Hemingway'in boğa güreşlerine merakı bundanmış. Bayılırmış babam da boğa güreşine. Babam boğa güreşçisi sanırdı kendini. $O$ bana iş gezileri sırasında İspanya' da gittiği boğa güreşlerini anlatır, ben boğayı düşünürdüm, ama en çok da atı. Bayır, çayır, yayla koşturacak, rüzgarla alabildiğine yarışacak bir at, arenada boğanın bir kaza boynuzuna kurban gidebilirmiş. Öyle heybetli heybetli dolanırken matadoru 1skalayan boğa onu kışkırtan matador yardımcılarını taşıyan o zavallı atların karnını bir darbede deşebilirlermiş de üstündeki canını kurtarabilirse kurtarırmış. Önce terbiye edil, sonra karnın deşilsin. Erkeklik zor. Ben erkek olamam. "Oley!" derlermiş boğa matadoru 1skalayınca, "Oley!" Ben öyle diyemem. Oley diyemem ben.

Ama o eldivenleri de giymekten vazgeçmezdi. O eldivenleri giyince ben ölürdüm. Duvara dönerdim yüzümü. Görmek istemezdim.

Babamda hikaye çoktu. Neler öğrendim ondan. En büyük, hatta hem en büyük hem de ilk büyük trajedi kahramanını anlatmaya da bayılırdı babam. Söyle bakalım pısırık, sabahleyin dört ayaklı, öğlen iki ayaklı, akşam da üç ayaklı olan şey nedir? He he he, bilemedin değil mi? İnsan, insan. İlk seferinde bilemedim, sonraları her soruşunda bir askerin komutanına "Sağol" çekmesi gibi "İnsan!" diye bağırıyordum, babam da "İnsan yaaa," diyerek döver gibi başımı okşardı. Bu insan bilmeesini Sfenks sormuş Oedipus'a. Babam kader diyor, Allahın dediği olur diyor. Tebaili Oedipus da dört ayaklıyken kahinler demiş bu bebek babasını öldürecek, anasıyla evlenecek ve çocuklarına kardeş 
olacak. Kral babası da ölümden korkarmış, vermiş bebek Oedipus'u bir çobana, git dağlarda öldür, demiş. Elleri ne kocamandı babamın.

Ama o kırbacı da almaktan vazgeçmezdi. Kırbacını da aldı mı ben tamam der kulaklarımı tıkardım duvarın önünde. Duymak istemezdim.

Çoban acımış tabii bebeğe. Götürmüş başka bir yerde çocuğu olmayan bir köylüye vermiş bebeği. Sonra kehanet gerçekleşmiş. Sfenks'in insan bilmecesinin cevabını bilip de kahraman olan Oedipus kehanetin gerçekleştiğini ancak ayak bileğindeki izden çoban onu tanıyınca anlamış. Kim olduğunu ancak o zaman öğrenmiş. İşte böyleymiş. İnsan ne oldum dememeli, ne olacağım demeliymiş. Sigara yerine puro içse daha yakışır gibi gelirdi bana. İpleri tutarken kocaman kocaman eldiven giyerdi yarılmasın elleri diye. Kitap okuyanın elleri yara bere içinde olmazmış. Babamın elleri sızlardı. Benim de sızlıyor şimdi ama biliyorum senin ölümüne de ben sebep olmadım. Babam yalan söyleyemez artık.

Ama o çizmelerini giymekten vazgeçmezdi. O çizmelerini giyince ben ölür ölür dirilirdim. Dirilmesem keșke derdim. Ölsem. Duvara dönsem hep.

Seni getirdikleri gün sesine uyandım çiftlikte. Babam daha yeni gelmiş şehirden. Ben bilmem babamın şehirde ne iş yaptı̆̆ını. Annem der bir işler çeviriyor amma... Emmim der Başbakan'ın sağ koludur. Milletvekilleri bile ondan korkar. Çiftlikte sanki bayram var. Hem babam gelmiş hem de sen. Sen, dünyadaki en güzel tay. Tay. O kadar güzeldin ki Tay sana ad koyamadan dellendim ben. "Tay" olsun o zaman adın senin. Beni affet. Şu yanı başındaki adam, hala senin iplerini elinde tutan zorbadır, o zorba işte seni bana vermeyen. Beni sana çok gören. Çok bağırdım, çok yalvardım babama, hepsine yalvardım seni terbiye etmesinler diye. Ben çok ölüyordum her tay terbiyesinde. Ancak boynuna kementler, yağlı sicimler geçince o mağrur edan sona erermiş, toprağı bu dünyanın tek efendisi benim der gibi arşınlayışın ancak boğulacağını sanırsan bir usluluk kazanırmış, ancak boynuna geçen sicimler her yandan çekiştirilince...ancak gözlerin yuvalarından dışarı uğrayınca Tay... ben de çok uslu bir çocukmuşum, bak herkes beni ne kadar çok seviyormuş, sen de benim gibi olacakmışsın, uslu ve sevimli. Yoksa asi olurmuşsun, alır başını gidermişsin, sen soluksuz kalana kadar çekmeleri gerekirmiş ipi, tay boğmak denirmiş buna. Kötü birşey yokmuş ki bunda, yoksa deli deli dolaşırmış taylar, uçan bir naylon torbadan bile ürkerlermiş, ancak ölümle böylesine yüz yüze gelince gerçek at olurlarmış, ancak soluksuz kalınca, ölümle soluk soluğa burun buruna gelince ancak...

Babam eldivenlerini giydi. Ben öldüm. Babam kırbacını eline aldı. Duvar yarılsa da içine girsem dedim. Kulaklarımı tıkamadım bu sefer. Gözümün önünde gözlerin, incecik ayak bileklerin, seni gördüğüm anda ben bulutlar arasındaki uçurtmaydım. Yarları, tepeleri aşardım seninle, ama seninle ancak koparabilirdim ipimi, yoksa o uçurtmanın uçuşu gibi yalancı uçuş olurdu. İpimin ucu babamın eldivenli ellerinde Tay. Ben böyle uçmak istemiyorum ki. Bulutlar bana kopar ipini diyor. Sen de gel ardımızdan diyorlar gidemiyorum, babam tutuyor ipimi. Sıkıyor sıkıyor. Ellerini uzat, diye bağırıyor. Koşuyorum. Koşuyorum...ellerimi ileri uzatmışım, yatağımda kanter içinde otururken buluyorum kendimi. Gene mi kabus gördün yavrum, diyor annem, derin derin iç 
geçiriyor avuç içindeki kınası üstünde ay kırılan emetem. Emetem yer yatağında öte yana dönüyor, annemin kadife elleriyle kollarım yorganın altına giriyor. Ay 1şı̆̆ 1 annemin buğulu gözleri.

Babam kırbacını da aldı. Ah duymasam o kırbacın sırtına indiğini. Duymayacağım. Duymadım da.

Çizmelerini giyerken babamı duydum ama. "Ankara'dan getirdiğim ithal iplerle boğacağız bu sefer çocuklar, ithal işkence ipinden getirdim"

Ben işkenceyi biliyorum. Çiftliğin salonuna parke döşeyen ustalar parkeleri döşedikten sonra lastikli kayış gibi bir şeyle parkeleri sıkıştırıyorlardı. O ne diye sorduğumda "gerdirme" dedi. "İşkence" de denirmiş, "cendere" de dendiği olurmuş. Parke parçalarını bir arada tutmak, dağılmalarını engellemek için bunu yapmak şartmış. Babam kendini gerdirmeye benzetirdi. Bu aileyi ben tutuyorum bir arada derdi. Ben olmasam haliniz harap derdi. Babam olmasa ailemiz dağılırmış, her birimiz yellerde savrulur, kurda kuşa yem olurmuşuz. Ne severdi bu ata sözünü. Kurda kuşa yem olurmuşuz.

Olduk da. Olalım da. Güneş nasıl kavuruyordu o öğlen. Seni terbiye edeceklerdi Tay. Boynuna geçen ilk kementten sonra gözlerin öyle büyüdü ki...daha sonra o gözleri Picasso'nun Guernica'sında gördüm. Sen boynundaki ipi hızla çektin. Koştun, koştun...ben de koştum...

Bu sefer yetişeceğim. Ölürüm yetişmezsem.

Babam, "alın şu boku ayağımın altından, ezilecek!" diye bağırıyor koşuyordu bir yandan da. Bok benim. Tay, senin aklına nerden geldi çiftliğin arkasındaki vadiye açılan yara doğru koşmak? Oysa ben gece denize benzediği şimdi aklıma gelen o vadide seninle birlikte y1ldızlara bakmak isterdim Tay.

Delleniverdim işte. Senin ipini kopartmış uçurtma gibi yardan aşağı uçtuğunu görünce...

"Tayyy!"

“Tay” ne güzel bir kelime. Söylerken, yüzüne bir gülücük yayılıyor insanın. Babam o anda att ithal ipten kemendini ve kocaman elleri her zamanki gibi mahirdi, sarıverdi kemendi senin o dal gibi narin boynunu. Gözlerin gene Guernica oldu. Seni yardan yukarı çekmeye çalışıyordu babam. İthal ip yardan aşağı gerildi gerildi. Gerdirme baba. $\mathrm{O}$ daha tay. Babam yavaş yavaş çekiyor seni. Gözlerin nasıl oldu öyle. Birazdan birkaç ithal ip daha geçecek boynuna, işkence yeniden başlayacak. Ellerime baktım. Ufacık lan ellerin senin, kız elleri gibi! Uzat lan ellerini, uzat da amcalar görsün erkek eli nasıl olurmuş! Rakı sofrasındaki amcalar ellerime bakacaklar gene, gülecekler kirli dişleriyle. Kız olacak birşeymiş bu yav! Gülerlerdi. Uzat bakiim ellerini!!!!

Ölürüm bu sefer yetişemezsem. 
Uzattım. Babamın yarın ucundaki çizmeleri kaydı. Kanatlanıp uçmak ister gibi sallıyor kollarını babam.

“Tayyy!!!”

Ben istemiyorum ki babam tay boğsun. O kayış gibi sert eldivenleri giymesin, kırbaç şaklatmasın, çizmeleriyle düşlerimi arşınlamasın. Sıkıldım, sıkıldık babamın heybetinden. Ah Tay. Ben istedim ki seni boğmasınlar. Ben istedim ki seni terbiye edemesinler. Sana da can havliyle kabul ettirsinler istemedim. Ben istedim ki...

Babamla birlikte yardan aşağı tam da üç yol ağzına...Aranızdaki mesafede ithal ip duruyor. İzi senin boynunda. Babam yerde Sfenks gibi yatıyor. Başı öne düşmüş Sfenks gibi.

İkisinin de boynu kırılmış, dedi biri. Duydum.

Sen dört ayaklısın, babam ise iki.

Şimdi çok uzaklardayım. Tay boğan, Zeytin öldüren, samanın altından su yürümüş o illere bir daha dönmem. Anadut memleket. Dirgen. Üç dişli çatal.

İp atlamıyorum. Annemin kadife elleri üstümde, emetemin kekikli bağrı aklımda, gözlerin hep gözümün önünde de ondan Tay. Ayaktayım.

Babam tay boğmayı çok severdi. Başka türlü ayakta duramazmış insan oğlu.

Haziran, 2000, Ankara 